\title{
Personal Grievances Arising from Redundancy: Life after Hale and the Employment Contracts Act 1991
}

\author{
Judith Ferguson*
}

Can an employer reorganise the workplace and make employees redundant without any obligations other than those specifically agreed upon? Redundancy has received only limited statutory attention in New Zealand and legal rights and expectations have not always been clear. The judgments of the Labour Court and the Court of Appeal in regard to the Hale case highlighted the conflicting considerations operative in the area and provided a useful guide to the current position. This article examines the role of the concept in personal grievances and offers comments on the significance of the Hale case and its implications for the future, taking account of the new Employment Contracts Act 1991 regime.

\section{Introduction}

The conflict inherent in the employer-employee relationship and the competing interests of the two parties to an employment contract are graphically illustrated in the dilemma involved in redundancy situations and in the difficulty the law in New Zealand has had in providing any resolution to this dilemma. In recent years the massive numbers of redundancies occurring have exposed the reality of this dilemma. Unemployment has increased dramatically and the position of employees is particularly weak. Employers have been struggling in a time of severe economic recession, with the viability of their businesses often under threat. Employees dream of job security or at least compensation if that is lost; employers want the freedom to make decisions they believe are necessary for the survival of their businesses, unhampered either in their ability to make those decisions or by crippling compensation payments.

In the legal arena, the dilemma has been expressed in an oscillating battle between, on the one hand, a recognition of the managerial prerogative of the employer to control his or her business and of the need for economic efficiency and, on the other, the employee's claim for security in his or her job and the more humanitarian need to protect the rights of the vulnerable, and to provide a remedy when those rights have been infringed.

It is the contention of this article that the Employment Court and its predecessors, in dealing with redundancy situations especially in the personal grievance setting, have displayed an ability to respond to the specific circumstances of the cases before them, to the rights and obligations canvassed by both parties, and to emerge with an interpretative framework capable of surviving even the major upheavals of the recent legislative changes. Rather than venturing to give unreserved support to the claims of either the employee or employer, the courts have cautiously balanced the competing interests in the context of the current social and economic climate, not ever closing the door completely on either party. 
This has been particularly interesting in the light of the advent of the Employment Contracts Act 1991. The legislators were committed to contract-based principles, to economic efficiency and to a reduction in the employees' bargaining strength, such a reduction being seen as an essential response to the economic needs of the time. Surely then, redundancy rights already largely dependent on only negotiated agreements, would inevitably be weakened if not lost altogether in this new regime. They could hardly be defended on the grounds of economic efficiency. In times of recession and high unemployment, it was unlikely they would be freely agreed to by employers. Thus, on the face of it, the death knoll had sounded with the Employment Contracts Act 1991.

It is argued, though, that the legal ramifications for employers and employees confronted with redundancies, and especially the remedies available in the personal grievance setting, have not been changed dramatically by the Employment Contracts Act 1991, and that the courts had already developed and formulated an approach and principles which had enabled them to deal with the intrinsic conflict of interests in the redundancy situation in a reasonably equitable way. This approach and the principles at work were fully reflected in the decisions of the Labour Court and of the Court of Appeal in G N Hale \& Son Ltd v Wellington, etc, Caretakers, etc, IUW (1990) 3 NZELC 97,696; (1991) 4 NZELC 95,310; [1991] 1 NZLR 151(CA). It is contended that these decisions will be of continuing significance under the new legislative regime.

In spite of the apparent determination of the legislators to reduce any expectations of a right to redundancy compensation in particular, it would seem that the Hale decisions may have paved the way for the establishment of a right to at least some minimal compensatory payment, even if there is no negotiated redundancy agreement, for employees dismissed for redundancy.

Subsequent cases have appealed to Hale to support the breadth of the managerial prerogative, and the freedom an employer has to make restructuring decisions which may lead to redundancies, (for example, New Zealand Meat Processors, etc, IUOW v Alliance Freezing Company (Southland) Ltd (1990) 3 NZELC 98,287; Bowater New Zealand Ltd v New Zealand Printing, etc, IUOW (unrep CLC 20/91, 11/4/91); Moffat Appliances Ltd v New Zealand Clerical Workers' Union (unrep CLC 55/91, 3/7/91)). But these rights, while no doubt strengthened by the objects of the Employment Contracts Act 1991, had long been recognised before its passing. In the cases leading up to the Hale decisions, there had been clear signs that the courts, when faced with personal grievances involving redundancies, had been willing to take into account factors such as the managerial prerogative of an employer to make the decisions needed to operate the business relatively unhampered by restrictive conditions (for example, Southland Clerical Workers' IUOW v Trilogy South Island Ltd [1988] NZILR 1180; Central Clerical Workers' IUOW v Mitsibushi Motors NZ Limited [1988] NZILR 359; Northern Clerical and Legal Employees', etc, IUW v Bruce Scott, Stevens and Partridge (unrep ALC 18/91, 29/2/91).

The courts had also been prepared to consider the genuineness of the redundancy situation claimed, looking at its reasonableness and fairness on the claimed facts and at whether the employer had genuinely held the reasons claimed for the decision (for example, Canterbury Hotel, etc, Employees' IUOW v Fabiola Fashions Ltd (1981) ACJ 439; New Zealand, etc, Shop Employees', etc, IUOW v Maidstone Hardware Ltd (1983) ACJ 585; Trilogy, supra, and New Zealand Cleaners, etc, IUOW v Ferrymead Historic Trust (1990) 3 NZELC 97,551). They had been influenced by the procedural and perhaps even substantive fairness of a dismissal (for example, Trilogy supra; Gee v Kinsman Group (unrep ALC 
150/89, 18/12/89); STAMS v New Zealand Rennet Co Ltd (unrep WLC 65/91, 22/7/91)). Factors such as the way an employer had selected a redundant employee from the workforce and whether the award provisions had been complied with had been considered along with the adequacy of the reasons given for the dismissal, although these were of less direct relevance to the Hale decisions.

Precedent too had not been disregarded. It had been of use in reinforcing decisions and in developing general principles. In spite of statements such as Finnigan J's that "comparison with ... other cases is unnecessary" (Avenues Restaurant Ltd (t/a Avenues Restaurant and Wine Bar) v Northern Hotel, etc, Employees' IUOW (unrep ALC 125/90. $17 / 10 / 90)$ ), one would be excused for concluding from the number of cases cited in many of the judgments that, in fact, the doctrine of precedent did have an active role. Considerable effort was often made to either follow or distinguish earlier cases. The traditional reliance of the general court system on the doctrine of stare decisis appears to have played its part in the reasoning of the specialist labour courts. For instance, Palmer J maintained: "Particular cases, of course, where staff dismissals arise, must be considered on their particular facts where the justification for any such dismissal is in issue. So much is trite." (Trilogy, supra, at 1193 per Palmer J). Yet he had made a very careful analysis of earlier cases before reaching a conclusion, just as he had done in many other redundancy cases (for example, Ferrymead, supra; Canterbury, etc, Stores, etc, IUOW v Tranzealand Freight Services Ltd (1989) 2 NZELC 96,574 and Canterbury \& Westland Stores Packing, etc, IUOW v South Pacific Tyres New Zealand Ltd [1988] NZILR 1412).

The Hale decisions provided the impetus for full judicial consideration of the legal significance, interpretation and consequences of redundancy in a personal grievance setting. They brought together much of the earlier law and the see-sawing findings at each court level illustrated the battle at play between the conflicting interests of the employers and employees. It is suggested these decisions of the Labour Court and Court of Appeal, although made before the passing of the Employment Contracts Act 1991, foreshadowed the provisions in that Act and will remain of continuing significance. However, before considering these decisions, their relevance in the present regime and their aftermath in more detail, a brief outline of the legislative background and statutory position as regards redundancy rights and obligations in New Zealand will be given so as to place the grievance provisions in some context.

\section{Legislative background}

In spite of a number of attempts to find legislative solutions to the problems arising in redundancy situations, and in spite of the rapid increase in the number of redundancies since the early 1970s, in New Zealand there have been no comprehensive measures akin to the English legislation (begun in the Redundancy Payments Act 1965, see Fryer (1973) and Grunfeld (1980)). Largely, rights and obligations have been left for employers and employees (through their unions) to settle between them in particular agreements.

Ever since it became apparent that the problem of redundancy was likely to have repercussions in the field of industrial relations, there have been calls for legislative measures to minimise these repercussions. These calls have come from both employers and employees, the former wanting to avoid industrial unrest and the latter wanting protection and compensation for lost jobs. 
Between 1972 and 1974 talks were held between the Employers' Federation, the Federation of Labour and the government, but by 1974 parties were still unable to agree on definitions and specific solutions. The matter was referred to the Industrial Relations Council and on its recommendation the Labour Government introduced the Severance and Re-employment Bill 1975. Minimum 'severance payments' were to be made and employers were to fund a retraining and relocation programme. However, after the change of government at the end of 1975 , the Bill lapsed. Measures of a very different nature were introduced in 1976 by way of Regulation 45A of the Wages Adjustment Regulations 1974, introducing the first New Zealand statutory definition of redundancy and setting a maximum level for redundancy payments. This regime was essentially continued until 1986.

With the major revision of employment legislation in the Labour Relations Act 1987, some clarification of the position regarding redundancy occurred, at least for those workers covered by the Act. The right of the parties to make redundancy agreements was formally recognised (s184), so that such agreements had full legal status and doubts as to the application of disputes and compliance procedures were removed. Strikes in support of redundancy negotiations were legal (s233(1)) and employers were not obliged to pay out in technical redundancy situations where a business was sold but the new employer had agreed to continue to employ workers on the same or better terms (s184A, inserted by the Labour Relations Amendment Act 1990, s20(1)). Section 184(5) also provided a definition for redundancy, based on the 1974 Regulations definition. Unless employers and employees had agreed on a specific definition pertaining to a particular award or agreement, the courts were likely to apply the definition found in s184, at least in personal grievance settings.

Even after 1987, then, there were still no comprehensive legislative provisions either enforcing, or restricting significantly, redundancy rights and obligations. National Governments had given employers some support in promoting limitations on the amounts to be paid out as compensation in redundancy situations. They had also provided further disincentives through directives such as that to the Department of Social Welfare in 1978, requiring that redundancy payments be taken into account before unemployment benefits were paid out. Labour Governments, while proclaiming support for unions and workers' rights, did not go as far as the English legislators in establishing a statutory obligation on employers to make redundancy compensation payments. They left it as a matter for employers and unions to negotiate, but did provide machinery to recognise, support and enforce any agreements made.

The passing of the Employment Contracts Act 1991 has been described, among other things, as the "most significant change in employment law and labour relations since 1894" (Towner,1991). In the move away from an emphasis on industrial relations and union protection and towards the promotion of "an efficient labour market", a strengthening of employees' redundancy rights was not to be expected. But nor, it would seem, have they been completely done away with. It would seem that there is still scope, in the personal grievance area at least, for some development, thanks to Hale.

There is no longer a statutory definition of redundancy included in the legislation. While employers have taken such an absence to imply that the negotiating parties are now free to "define what 'redundancy' is (in their terms)" (New Zealand Employers' Federation, 1990 ), they were in fact always free to do so and the courts have always been prepared to recognise the definitions they have formulated. It has only been in the absence of a definition within an instrument that the courts have imposed their own definition, and it is likely that the judicial approval given by the Court of Appeal in Hale for the use of the Labour Relations Act 1987, s184 definition will survive. This was the definition Cooke P held 
corresponded to ordinary usage. Unless the ordinary usage changes, there would seem to be no need to move away from that definition. There is reinforcement for this view in s176(5) of the new Act where, for the purposes of redundancy provisions which survive in existing awards or agreements, "the term 'redundancy' shall ... have ... the same meaning as it had immediately before the commencement of this section."

Section 76(5), as amended by s 2 of the Employment Contracts Amendment Act 1991 (no 98), also continues the provisions for technical redundancies. When a business is sold, employers are not required to pay redundancy compensation if the new owner agrees to offer continued employment on equivalent or better terms.

There is no longer any specific provision for negotiating and registering redundancy agreements. Redundancy is just one of many matters to be included in an employment contract, either individual or collective, if the parties agree to do so. While there has never been a requirement that redundancy provisions be included in an award, the bargaining strength of the unions often led to such provisions even though the employers may have been reluctant. It is likely, though, that in difficult financial times and freed from the negotiating influence of the unions, employers will be extremely reluctant to agree voluntarily to redundancy provisions. Indeed, the Director-General of the Employers' Federation has advised members to consider "negotiating their way out of redundancy agreements", maintaining that the concept has "got out of hand", and that it is now realistic for employers to refuse to have any responsibility for redundant workers (Otago Daily Times, 10 April 1991).

Registered redundancy agreements already in existence when the Employment Contracts Act 1991 came into force are able to survive unless they have an expiry date or the parties agree to change them $(\mathrm{s} 176(4)){ }^{1}$ In contrast, existing awards (and presumably redundancy provisions contained within them) will, unless a new agreement has been reached, continue in the guise of individual employment contracts even after their expiry date has passed (s19(4)). The status of redundancy agreements made outside the employment contract is of particular doubt, as was reinforced by the decision in Hands and Anor $v$ WEL Energy Limited (unrep CA 262/91, 31/12/91). As a result it would appear that unless incorporated within the employment contract, such agreements, standing alone, may well not be amenable to the jurisdiction of the Employment Court. ${ }^{2}$ Overall, redundancy agreements will receive

1 This change may not have immediate impact as "An analysis of registered redundancy agreements has revelaed that most redundancy agreements (nearly 450) do not contain a definite date of expiry but only a minimum term, 23 agreements contain no expiry date at all, and 29 agreements have terms of three years or more. Accordingly, many employers will continue to have binding obligations to notify their employees of impending redundancies and to pay them redundancy compensation of a prescribed amount usually dependent on length of service." Towner, (1991) at p.116.

2 It is possible that a redundancy agreement made outside the terms of an employment contract, that is, as a separate agreement, negotiated independently of the contract of employment, will not be amendable to the specialist courts' jurisdiction and the parties will have to look to the general law of contract for any protection. The Employment Tribunal and the Employment Court have exclusive jurisdiction over proceedings founded on an employment contract, that is a "contract of service" (s2 definition) and the enforcement part of the Act, Part IV, also applies only to "employment contracts". The functions of the Employment Tribunal, however, include assisting employers and employees "to achieve and maintain effective employment relations, in particular, by facilitating mutual resolution of differences between the parties to employment contracts" (s78(1)). It is to "adjudicate a settlement of differences between parties to employment contracts" $(s 78(3)(b))$. Section 79 , which outlines its jurisdiction, does 
even less legislative protection and encouragement than they did under the Labour Relations Act 1987.

In particular, the legislators have made an effort to exclude the Employment Court from actively participating in the setting of reasonable redundancy payment quantums. Under the Labour Relations Act 1987 regime, if there was a redundancy provision in an award which provided for negotiation of a settlement in the event of redundancies, but the parties were unable to agree on an amount, the courts had used the disputes provisions to enable them to actually set the payment levels (Timbercraft Industries Ltd $v$ Otago and Southland Federated Furniture, etc, IUOW (1990) 3 NZELC 98,124). One of the objects of Part IV of the Act is to refuse enforceability of terms which provide for further negotiations (s43(c)) and s46(3) specifically precludes the Employment Tribunal and the Employment Court from setting either the formula or level for a redundancy payment if it is not specified in the contract.

But in spite of - or perhaps in response to - these efforts to restrict the role of the courts in awarding compensation payment for redundancy, it would still seem possible for employees dismissed for redundancy under a contract of employment containing no redundancy agreement, to gain some monetary compensation through the Employment Courts. To do so, like Mr Shrubshall in Hale, they would have to apply through the personal grievance channels and establish that the dismissal was unjustified because, in all the circumstances, inadequate compensation was made.

The legislation seems to point to a requirement that any rights to compensation payments in particular must spring from the negotiated agreement between the parties, but there are indications that the Employment Courts are willing to consider a right to such compensation even when there was clearly no such agreement in the employment contract. It is as if the Employment Courts, in some instances at least, have responded to the weakening of the bargaining strength of the employee with a countering gesture of support, be it minimal, in spite of the legislative constraints.

\section{Redundancy and personal grievances}

Although the legislation both before and after 1991 did not establish redundancy rights and obligations per se, as already noted, a body of law was built up in the personal grievance arena, culminating in the Hale decisions, which seemed to indicate that there were in fact legal expectations in redundancy situations wider than those directly prescribed by the legislation. These actions generally came under the unjustified dismissal head.

On the face of it, the unjustified dismissal regime did not offer much in the way of relief to the employee who had been made redundant. It had been clearly established that an employee dismissed on the grounds of a genuine redundancy had not been dismissed unjustifiably (for example, Auckland Amalgamated Society of Shop Assistants IUW $v$ Curtain Styles Ltd (1978) ACJ 53). The courts had consistently applied this principle. However, the range of remiedies available, the lack of a restrictive definition for an unjustified dismissal,

give it power to "exercise such other powers and functions as are conferred on it by this ... Act" $(s 79(1)(j))$. Whether these provisions could be read so as to include differences arising between the parties to an employment contract, but concerning a matter within a collateral agreement, is somewhat doubtful. 
the use made of the court's powers 'in equity and good conscience' and the lack of direct legislative protection for redundancy situations have all invited grievants to explore the personal grievance area as a possible source of rights in a redundancy situation. The courts have responded to these initiatives, but their responses have again reflected their appreciation of the complexity of the problem and the competing interests of employers and employees.

Personal grievance actions alleging unjustified dismissal and involving redundancy issues have centred mainly around two questions:

1. Was the alleged redundancy a genuine one? (If it was not, the dismissal was unjustified.)

2. If there was a genuine redundancy, was the dismissal rendered unjustified by any other factors?

It was against this background, then, that the plight of a cleaner, dismissed in the course of his employer's cost saving efforts, came to the attention of the specialist labour courts in the Hale grievance.

\section{Hale}

By 1989 the unemployment level was at an all time high. ${ }^{3}$ Employers were under pressure in a recessionary economy; the viability of many businesses was threatened. They wanted to be able to adjust their affairs, to economise, to reorganise, to restructure, to lay off staff if necessary in order at least to survive if not remain profitable. They were on edge. At the same time employees were aware that their livelihoods were at risk. Their jobs were no longer secure and they were anxious lest they become the next victims in the drive to economise, and in the unemployment surge. They wanted to preserve their jobs and retain their conditions of employment and they recognised a real threat in employers' attempts to replace them with cheaper alternatives. The clash of interests evident in any redundancy situation had been heightened by the economic reality and the political philosophy of the time.

Another of the players in this scene was the employment court system with its two strong but potentially conflicting traditions. Its specialist jurisdiction required that it operate in equity and good conscience, considering each case on its own particular facts and merits. Yet it was a judicial institution sharing certain features common to the other courts in the legal system, firmly grounded in the doctrine of precedent, concerned with consistency and predictability, with justification and reason.

At that time, as now, there were no clearly defined redundancy rights and obligations in the existing labour legislation, only a right to negotiate a redundancy agreement if both sides were agreeable. However, through the use and application of the procedures in the general labour relations legislation, certain expectations had been built up, protected and enforced by the courts. In very broad terms, if workers were dismissed for redundancy, they could expect any existing redundancy agreement to be adhered to and, if not, there were remedies available to them. If there was no existing agreement but there were provisions for

3147,866 were reported as unemployed in February 1990 when Mr Shrubshall's case first reached the Labour Court. (Key Statistics: a monthly abstract of statistics, Department of Statistics, Wellington, December 1990) 
negotiating one, in certain situations they might seek the assistance of the courts in attaining such an agreement. There were also remedies available for employees dismissed unjustifiably, and the courts had developed ways in which these remedies had become available to grievants dismissed unfairly, either substantively or procedurally, in a claimed redundancy situation.

But many factors operated in the process of reaching decisions over disputes or grievances, factors such as respect for legislative expression; respect for the managerial prerogative; respect for the need to protect employees; respect for the principles of good labour relations; respect for promoting an efficient labour market; respect for traditional legal concepts such as natural justice, freedom of contract and the sanctity of contract; and consideration of specific factors which may influence any particular situation.

All of these vied for recognition and resolution in the drama which unfolded around Mr G Shrubshall, cleaner for G N Hale and Son Ltd, dismissed for redundancy on 14 July 1989.

The decisions of the Grievance Committee, the Labour Court and the Court of Appeal provided a fascinating illustration of the interplay between those competing interests and influencing factors which have already been referred to - factors which have operated both in the legislature's reluctance to enshrine redundancy rights and obligations in legislation, and in the courts' difficulties in reaching consistent solutions and setting clear guidelines. As $\mathrm{Mr}$ Shrubshall's case progressed through the Grievance Committee to the Labour Court, on to the Court of Appeal and back to the Labour Court, none of the decisions or their reversals were really surprising or unpresaged in the earlier cases, except perhaps in their implications with regard to the need for compensation payments. Each decision and justification had been foreshadowed. They simply illustrated the various forces at work, and the ability of the courts to respond to, and take into account, a wide range of different factors, both factual and legal, in redundancy situations.

\section{The facts}

G N Hale and Son Ltd had employed Mr Shrubshall for almost two years at a plant which, it claimed, was operating at only a marginal level of profitability. In April 1989 a severe drop in monthly sales figures prompted the management to formulate a cost-saving plan involving re-employing one worker on a contract basis, cancelling the free transport provisions for all workers at the plant and replacing Mr Shrubshall with a contract cleaner, distributing his non-cleaning responsibilities among the other workers. Eventually $\mathrm{Mr}$ Shrubshall was indeed dismissed, but it was against a background of industrial disharmony. The rest of the workers had objected strongly to the cost-cutting measures, their union had begun to formulate a claim for redundancy payments and when talks broke down a fortnight after Mr Shrubshall's dismissal, the other workers embarked on a five week strike.

The employer had not breached any terms of Mr Shrubshall's award, there being no requirement for prior union notification or for union attendance at a dismissal interview. He had been paid four weeks pay in lieu of notice and promised an extra $\$ 2,000$ as redundancy compensation even though no compensation was required by the award at the time of the dismissal.

He was given no advance warning of his actual dismissal and was given formal notice in a 10-15 minute interview. This notice was confirmed by letter both to him and his union, 
stating that the reason for his dismissal was redundancy, brought about by a need to rationalise "in light of the present business environment".

The union brought a personal grievance action on Mr Shrubshall's behalf, claiming that he had been unjustifiably dismissed both procedurally and substantively.

\section{The decisions}

The Personal Grievance Committee found that the dismissal was justified and the redundancy genuine. In spite of doubts as to the economic wisdom of the company's decision, the Chairman recognised the employer's right to adjust a business for economic reasons; the managerial prerogative prevailed.

The union appealed the Committee's decision on the grounds that the redundancy was in fact not a reasonable and competent business decision, that it was substantively unjustified and implemented in a procedurally unfair manner. In a long judgment, Goddard CJ concluded that the dismissal was neither substantively nor procedurally justified. Reinstatement and reimbursement for lost wages were ordered.

The submissions of the advocates for the union, and the invitation they issued to Goddard CJ, were crucial to the direction this judgment took and to its outcome. In earlier cases, if redundancy had been relied upon as the dismissal ground, challenges to its genuineness had been directed at the specific reasons given for the employer's decision. If an employer claimed the decision was necessary because of economic necessity, the decision was seen as genuine only if there was sufficient evidence of that economic necessity. If a significant downturn in business was the reason given, again evidence of such was needed to establish that it was the real or genuine reason for the redundancy. This had been the pattern in earlier cases.

However, the union advocates in their first appearance for Mr Shrubshall in the Labour Court argued that the redundancy was not genuine because the dismissal was not based on commercial necessity to ensure the ongoing viability of the employer's business. They continued their submissions with claims that the employer had not acted as a competent businessman in the way the whole situation had been dealt with, leading as it did to foreseeable industrial conflict and strife, and that if there was not pressing financial necessity to make changes, there was a higher duty on an employer to consult and consider alternatives before deciding on redundancy. On the facts, it was argued the employer's rigid and fixed attitude amounted to procedural unfairness.

The employer did not, at least according to the judgment, argue that commercial necessity in the sense of capacity for survival gave rise to the redundancy decision. Rather, it was submitted that the decision was a genuine decision made for proper motives, within the scope of the employer's right to manage a business.

Goddard CJ accepted the union advocates' invitation to examine the genuineness of the redundancy in terms of not only good faith and the genuineness of the reasons given, but also in a substantive sense. What were the conditions which would justify an employer making an employee redundant? This was an invitation to intrude into the managerial prerogative and define what would be acceptable business reasons for reorganising the workforce. Was economic desirability enough or did it need to be economic necessity before an employer would be justified in dismissing an employee?

Goddard CJ cited a host of cases in support of his conclusion that, for a dismissal for 
redundancy to be justified, it must be shown to be commercially necessary in the sense of being essential for business survival. The cases cited, though, do not seem to point to such a conclusion, but rather to a requirement that the reasons relied upon by the employer are genuine and substantiated by sufficient evidence.

Goddard CJ's consideration of fair and reasonable treatment procedurally was more in keeping with the authority cited in support there.

The judgment focused very much on the employee's plight, the importance of employment and the effect of the dismissal on him, going so far as to suggest ways employers might avoid dismissals in times of economic pressure by strategies such as, "alternative savings of overheads or expenses, steps to increase sales or other income, retraining, attrition, transfers between departments and all possible measures for avoiding or minimising the effects of the dismissals of the workers concerned." (p.97,718)

It is clear Goddard CJ was not going to be precluded from examining the employer's decision on its merits and, while claiming it would be wrong to lay down rigid rules, he clearly set a requirement on an employer to show economic necessity, not desirability or convenience in order to justify a dismissal for redundancy.

The employer's rights found favour, on the other hand, with the Court of Appeal when G N Hale and Son Ltd appealed the Labour Court decision by way of case stated. What was questioned was whether a dismissal on the grounds of redundancy needed to be genuine and unavoidable and, in order for it to be justified, whether it needed to have been commercially necessary in the interests of the viability of the employer in the sense of capacity for survival. Clarification was also sought on the role of a compensation payment in any justification for dismissal. The findings of the Labour Court in regard to procedural unfairness were not challenged.

In a unanimous decision of a full bench, the Court of Appeal found that it was not necessary to apply a test of necessity for survival nor to show that a redundancy was unavoidable before a dismissal would be justified. What was to be established was the genuineness of the decision, the credibility of the employer, the good faith and proper motives, not the commercial wisdom of the decision.

All five judgments were in stark contrast to that of Goddard CJ in the Labour Court. They were based on broad principles, not precedent, and those principles clearly reinforced the managerial prerogative. The Court of Appeal did not follow the dubious route Goddard $\mathrm{CJ}$ had taken through the earlier case law. Nor was it swayed by the specific plight of $\mathrm{Mr}$ Shrubshall and the particular facts of his case. Rather, it took a much wider view and applied broad principles and arguments, particularly those on which the managerial prerogative rests.

In terms of the reinforcement of the managerial prerogative, and rejection of a substantive test of economic necessity for a justified redundancy dismissal, the Court was unanimous and clear. The question of the role of a compensation payment and the obiter dictum referring to procedural fairness were far less so. The judgments have raised doubts as to whether an employer is now expected to offer compensation in order to justify a dismissal for redundancy on economic grounds such as those in Hale's case.

Somers $\mathrm{J}$ and Bisson $\mathrm{J}$ in particular may have left open the door for a requirement that compensation be paid even when not required by the award or agreement. Somers J stated "Whether dismissal is attended with fair and reasonable treatment will normally depend on whether it is accompanied by reasonable compensation where the circumstances call for it." (p.158). And while "the circumstance" might be confined to the award or agreement terms, it was clear from the judgment of Bisson $\mathrm{J}$ that for him such a restriction was not intended: 
Where there is no current registered redundancy agreement or the award does not deal with compensation for redundancy, it follows that whether a dismissal for redundancy amounts to an unjustifiable dismissal or not turns on the question whether the circumstances call for compensation and, if so, what would be an appropriate amount in the prevailing circumstances. (p.159-160)

Precedents for this view, though not so broadly stated, could still be found in the practical outcomes of cases such as Wellington and Taranaki Shop Employees', etc, IUOW $v$ Pacemaker Transport Wellington Ltd [1989] 2 NZLR 762 and Gee v Kinsman Group (supra). The distinction between the notion of redundancy compensation payments under an award or agreement and the compensation imposed as the result of an unjustifiable dismissal, in practical terms, may have been blurred. Even in the past there seem to have been circumstances in which the courts have been prepared to recognise redundancy compensation as an expectation, and its absence may have contributed to a finding that the dismissal was unjustified and resulted in a compensation award equivalent to what might have been expected under a redundancy agreement.

The Court of Appeal remitted Mr Shrubshall's case to the Labour Court to be reconsidered in the light of its findings. Goddard CJ now accepted that redundancy was the genuine reason for the dismissal and so in that sense the dismissal was substantively justified. But he then went on to consider the amount of compensation offered. It was argued that the implied term of fair and reasonable treatment was still breached because some situations, such as a voluntary, cost-saving redundancy where the employer can afford reasonably to pay redundancy compensation, require that adequate compensation be paid, even in the absence of an express agreement. Goddard CJ indicated that, if employers choose to exercise their right to manage to the extent of creating redundancies where they are not absolutely necessary, then they must accept an obligation to pay reasonable compensation even if it has not been agreed to. If they do not do so, they have not acted as fair and reasonable employers. Goddard CJ went as far as to conclude that by paying redundancy compensation the employer was admitting that without it, the dismissal would have been unjustified.

On the facts of Mr Shrubshall's case he did not think the compensation offered was adequate and so the dismissal was still found to be unjustified - and if not for that reason, he was also prepared to find it unjustified because of procedural unfairness. ${ }^{4}$ Reinstatement was no longer seen as an appropriate remedy, for if a genuine redundancy existed, the position was, in effect, no longer there. Compensation was therefore awarded - $\$ 3,000$ for the redundancy payment and $\$ 2,000$ for humiliation, loss of dignity and injury to feelings, this being for the effects of the dismissal over and above the injury resulting from the loss of the job alone.

It is clear from Goddard CJ's judgment that he had considerable sympathy for this particular employee, for his vulnerability and bewilderment and for the way he had become a victim of a wider industrial problem. He had struggled throughout his two judgments with the conflicting influences of the power of precedent, the needs and strength of the employer,

4 It is pertinent to note here that in the Employment Contracts Bill, introduced on 20 December 1990, there was indeed a provision which would have ousted procedural faimess as a sufficient reason on its own for finding a dismissal unjustified (cl 17(3)). In the final version of the Bill, however, this provision was omitted. This may be interpreted as indicating that it was Parliament's intention that procedural faimess ought to continue to be regarded as a sufficient reason to hold a dismissal unjustified, even in a redundancy situation. 
the realities of the business world and the vulnerability of the employee. At the end of the day he was able to provide only limited relief for Mr Shrubshall. His job was irretrievable, but at least the employer had been warned that along with the rights to control the workforce came also a duty to treat it fairly and, the greater the exercise of the prerogative, the higher would be the requirements of fairness.

There was probably no 'winner' in Mr Shrubshall's drama. The employer's freedom to make business decisions was reaffirmed but it was limited. The employee's protection from job loss may have been weakened but the rights to compensation and fair treatment were probably strengthened.

\section{The aftermath}

The subsequent uses made of the Hale judgments have shown the extent to which they gave support to both employer and employee in redundancy situations. As noted earlier, they have been used to support the employers' claims to a broad managerial prerogative. For the employee they have been used to support the need for procedural fairness in employment relations which involve redundancies (for example, New Zealand Performance and Entertainment Workers' Union v Leisureland West Auckland Ltd (unrep ALC 21/91, 15/3/91)) and to support the argument that a lack of adequate compensation may contribute to a dismissal being unjustified (for example, Leisureland, and New Zealand Workers' Union IUW v Sarita Farm (unrep CLC 17/91, 26/3/91)).

The decision in Sales Representatives Guild $\mathrm{v}$ Benjamins Ltd (t/a Stewart Bell Benjamin) (unrep CEC 18/92, 1/5/92, Palmer J) has been the clearest indication of support for this direction suggested by Somers $\mathrm{J}$ and Bisson $\mathrm{J}$ in the Court of Appeal. In this case, as in Hale, the dismissal was one found to be made for genuine reasons of redundancy and, although claimed otherwise, Palmer $\mathrm{J}$ found there had been no agreement or commitment to pay redundancy compensation. The employer had met all the express requirements of the employment contract. It had gone further in awarding a lump sum equivalent to two months salary.

Although Palmer J held that the level of compensation paid to other employees in similar positions was irrelevant, he did indicate that in certain cases compensation may be needed to render a dismissal justified, even if there are no provisions for such payment in the contract of employment. On the facts of the case before him he found the amount paid out was "justly appropriate", having regard particularly to the parlous state of the company, and so the dismissal was justified.

Again, while the judgment contains strong rhetoric in support of the managerial prerogative and the employer's right to make his or her business more efficient and to make such business decisions free of interference from the courts, the employee has not been left entirely at the mercy of the exercise of this prerogative. He or she is clearly regarded as being entitled to "justly appropriate" redundancy compensation payment, even if not included in the employment contract. The courts are willing to look at the ability of the particular employer to pay such compensation and at factors such as the length of service and quality of the employee's work performance in determining just what would be an adequate payment. While this amount may well be low in times of economic hardship for employers, it is conceivable that the same principle may entitle an employee to more generous payments in more affluent times. An inadequate sum in the particular circumstances would be sufficient 
to render a dismissal unjustified.

It is suggested that this approach has left it possible for the courts in effect to reassess the quantum of redundancy payments in personal grievance proceedings at least. In the disputes area, Parliament has already made it clear that the role of the courts in determining redundancy amounts is to be limited (s46(3) of the Employment Contracts Act 1991) and, in keeping with a stricter contractual approach, the courts have been less able to venture beyond the actual terms agreed to in the employment contract. (See, for instance, Southern Drivers' Union v Tulloch Transport Ltd (unrep CLC 50/91, 7/6/91), in which Palmer J was not prepared in a dispute of rights action to require an employer to pay compensation to employees made redundant in a restructuring action when the express agreement did not require it.)

\section{Conclusion}

The conflicting interests inherent in redundancy problems continue to vie for attention in personal grievance considerations. This is so in spite of what appears to have been a determined effort on the legislators' part to tip the balance in favour of employers, and away from any legal right to, or expectation of, redundancy compensation. Recent moves on the part of the Government have given further indications of this resolve to discourage the parties from even reaching agreement over redundancy payments, by rendering compensatory payments far less attractive to both employer and employee. There are no direct guidelines or restrictions on redundancy payments, but s60(2) of the Social Security Act 1964, as amended by the Social Security Amendment Act 1991, provides that, as from March 11991 , eligibility for unemployment benefits and family support will be deferred until after redundancy payments, treated as income, have ceased to have effect. In other words, redundancy payments are treated not as compensation for the loss of a job, but rather as 'tide-over' payments to replace lost income. On May 61992 the Redundancy Payments (Taxation and Benefits) Bill was introduced, designed to remove the concessional tax rates on redundancy payments and the fringe benefit burdens on employers and replacing them with a $28 \mathrm{c}$ in the dollar rate on employees. Encouragement for low payments was reinforced by the removal of the 26-week benefit stand-down period for those receiving payments of less than $\$ 9,870$. In a press statement by the Minister of Labour on 10 September 1992 a further blow was dealt and the position of the Government made clear:

\footnotetext{
"The Government believes that redundancy provisions should not be part of the statutory minimum code governing employment contracts and does not intend intervening in the labour market to insist on minimum redundancy. "Redundancy has always been a matter of negotiation between employers and employees under both previous industrial relations law and the Employment Contracts Act". From 30/11/92, redundancy will be taxed as income to "address the issue of unfairness created by the almost negligible tax liability" some very large redundancy payments have attracted." (as noted in (1992) 15 Capital Letter 3)
}

In the face of this determination by the Government to render redundancy payments a thing of the past, the courts have still persisted in giving support to the interests of the employee. In situations such as those in Hale and in the Benjamins case, this support may still be of some practical benefit and may foil the efforts of the legislators in a small way at least: compensation payments awarded under the personal grievance provisions would not 
be subjected to these rigorous taxation and benefit measures.

The Hale decisions provided a useful insight into the way redundancy situations were regarded by the law in 1990 and, together with the understanding gained by an exploration of the earlier history, may assist in predicting future directions. The major changes brought about in 1991 by the passing of the Employment Contracts Act and the economic climate in which it now operates may have indicated a weakening of the rights of employees. But the popular belief of many that redundancy allowances are "only a social and moral obligation these days" (Otago Daily Times, 11 September 1991) does not accord with the implications that can be drawn from the Hale judgments, the legal tradition that gave rise to them, or the way the employment courts have responded to such legislative weakening. The conflict between employers' and employees' interests in redundancy situations seems to have been mirrored at times in the battle between the legislators and their defence of employers' interests and the courts and their preservation of some small comfort for employees.

Employees dismissed for redundancy can still expect that the terms of their contracts will be honoured and, even in the absence of any specific redundancy provisions, should be able to expect fair and reasonable treatment which may even extend to a requirement that some redundancy compensation be paid to them.

\section{References}

Fryer, R.H. (1973), The Myths of the Redundancy Payments Act, Industrial Law Journal 2: 1 .

Grunfeld, C. (1980), The Law of Redundancy, London, Sweet and Maxwell, 2 ed.

New Zealand Employers' Federation (1990), Draft Submissions to the Labour Select Committee on the Employment Contracts Bill.

Towner, R.L. (1991), Employment Law, New Zealand Recent Law Review, 1991: 103.

\section{List of Cases}

Auckland Amalgamated Society of Shop Assistants' IUW v Curtain Styles Ltd (1978) ACJ 53

Avenues Restaurant Ltd (t/a Avenues Restaurant and Wine Bar) v Northern Hotel, etc, Employees' IUOW (unrep ALC 125/90. 17/10/90)

Bowater New Zealand Ltd v New Zealand Printing, etc, IUOW (unrep CLC 20/91, 11/4/91)

Canterbury \& Westland Stores Packing, etc, IUOW v South Pacific Tyres New Zealand Ltd [1988] NZILR 1412

Canterbury, etc, Stores, etc, IUOW v Tranzealand Freight Services Ltd (1989) 2 NZELC 96,574 
Personal Grievances Arising from Redundancy 385

Canterbury Hotel, etc, Employees' IUOW v Fabiola Fashions Ltd (1981) ACJ 439

Central Clerical Workers' IUOW v Mitsibushi Motors NZ Limited [1988] NZILR 359

Gee v Kinsman Group (unrep ALC 150/89, 18/12/89)

G N Hale \& Son Ltd v Wellington, etc, Caretakers', etc, IUW (1990) 3 NZELC 97,696; (1991) 4 NZELC 95,310; [1991] 1 NZLR 151(CA)

Hands and Anor $v$ WEL Energy Limited (unrep CA 262/91, 31/12/91)

Moffat Appliances Ltd v New Zealand Clerical Workers' Union (unrep CLC 55/91, 3/7/91)

New Zealand Cleaners', etc, IUOW v Ferrymead Historic Trust (1990) 3 NZELC 97,551)

New Zealand, etc, Shop Employees', etc, IUOW v Maidstone Hardware Ltd (1983) ACJ 585

New Zealand Meat Processors', etc, IUOW v Alliance Freezing Company (Southland) Ltd (1990) 3 NZELC 98,287;

New Zealand Performance and Entertainment Workers' Union v Leisureland West Auckland Ltd (unrep ALC 21/91, 15/3/91)

New Zealand Workers' Union IUW v Sarita Farm (unrep CLC 17/91, 26/3/91)

Northern Clerical and Legal Employees', etc, IUW v Bruce Scott, Stevens and Partridge (unrep ALC 18/91, 29/2/91)

Sales Representatives Guild v Benjamins Ltd (t/a Stewart Bell Benjamin) (unrep CEC 18/92, 1/5/92, Palmer J)

Southern Drivers' Union v Tulloch Transport Ltd (unrep CLC 50/91, 7/6/91)

Southland Clerical Workers' IUOW v Trilogy South Island Ltd [1988] NZILR 1180

STAMS $v$ New Zealand Rennet Co Ltd (unrep WLC 65/91, 22/7/91)

Timbercraft Industries Ltd v Otago and Southland Federated Furniture, etc, IUOW (1990) 3 NZELC 98,124

Wellington and Taranaki Shop Employees', etc, IUOW v Pacemaker Transport Wellington Ltd [1989] 2 NZLR 762 